\title{
THE EFFECT OF SKIMMING METHOD TO IMPROVE STUDENTS' ABILITY IN READING COMPREHENSION ON NARRATIVE TEXT
}

\author{
BOBBY PRAMIIT SINGH DHILLON', HERMAN², SYAFRYADIN ${ }^{3}$ \\ Universitas HKBP Nommensen' \\ Universitas HKBP Nommensen ${ }^{2}$ \\ Universitas Bengkulu ${ }^{3}$ \\ bobbydhillon2002@yahoo.com', herman@uhn.ac.id², syafryadin@unib.ac.id ${ }^{3}$
}

DOI : http://dx.doi.org/10.29300/ling.v6i1.2991

Received: April 2020

Accepted: May 2020

Published: July 2020

\begin{abstract}
This research aims to know the effect of using skimming method in teaching reading comprehension AT SMK Negeri 2 Pematangsiantar on narrative text. The problem of this research are (1) what is the students' ability in reading without using skimming method at Grade XI students' of SMK N.2 Pematangsiantar. (2) what is the students' ability in reading by using skimming method at Grade XI students' of SMK N.2". The purposes of this research are to find out the students' ability in reading without using skimming method at grade XI students in SMK N 2 Pematangsiantar on reading narrative text and to find out the students' ability in reading by using skimming method to the skill of grade XI students in SMK N 2 Pematangsiantar on reading narrative text. To answer the problems, the researchers used theories: Micklukey and Jefferies (2007), Grellet (2000), Milter (2001), Jhon and Dara (2005), David Nunan (1991), Douglas Newton (2000), Douglas Brown (2003), Rae Pica (2000), Roger Brown (1973), Ronald Carter (1998), Scoot Thornburry (2002), Wilga Rivers (1987), Diane Larsen (1990), Judi Willis (2008), Jack and Theodore (1986). This study employed a quantitative research. As an experimental research, it aims to know the effect of the technique that given and apply whether it influences to the object or no. In this research in collecting the data the researcher has to do three steps, they are pre-test, treatment, post-test. The researchers find out that the effect of using skimming method can increase the students' skill in reading of narrative text. It can be proven from the test of students' score in post-test of experimental class which the treatment the researchers did the treatment by using skimming method. By using skimming method, the students can increase their ability in reading of narrative text.
\end{abstract}

Keywords: Effect, narrative, reading comprehension, skimming

\section{INTRODUCTION}

Hutajulu and Herman (2019:29) stated that language is as the tool of communication that has the essential part in making communication. Hence, language is primarily human and non-instinctive method of communicating ideas, emotions, and desires by means of a system of voluntarily produced symbols (Sapir, 1921:17 as cited in Herman, 2014:1). From the definition, it is important to note that language is a means of communication purely owned by human. Language is an important part of how humans communicate with each other. It is no small thing! Through language, we learn how to "mean things" and how to share all of those meanings with others. The story of how those meanings are created and shared is truly the story of the human family. It is our distinctly human endowment.

How to cite this article: Dhillon, B., Herman, H., \& Syafryadin, S. (2020). The Effect of Skimming Method to Improve Students' Ability in Reading Comprehension on Narrative Text.. Linguists : Journal Of Linguistics and Language Teaching, 6(1), 77-88. doi:http://dx.doi.org/10.29300/ling.v6i1.2991 
Communicating in English is one skill that the students have to master. They must know the rules of English grammar in order to avoid making errors or mistakes. They have to master the structure of English, so that they will be able to put their ideas, feeling, or desires into the grammar of English to make them meaningful.

English has been used by many people from different countries. Most of non-active speakers use English to establish relationship with other people coming from countries. In Indonesia, English has a very important role in technological and scientific and advance; instrument such as computer and interact use also used as a means of communication within international tread and business. Consequently, people who want to have access to them should master English well. In English there are four skills that should be mastered, they are listening, speaking, reading, and writing.

Among those four skills, reading becomes very important in the education field, where students need to be exercised and trained in order to have a good reading skill. Reading is also central to a student's experiences at school and in everyday life. Thus, teaching students to read is a major taskfor reading teachers today. Since students arrive at schools at different reading developmental stages, reading teachers, therefore, are faced with helping less capable readers improve their reading skills by providing the best reading instruction possible. Reading is a constantly developing skill. Like any skill, we get better at reading by practicing. Meng (2010:501) as cited in Herman, Sibarani and Pardede (2020:86) stated that English reading has always been regarded as one of the main aims in English teaching in colleges and universities, because it can objectively reflect the students'abilities to acquire the language.

Conversely, if we do not practice, we will not get better and our skills may deteriorate. Reading integrates visual and nonvisual information. During the act of reading, the visual information found on the page combines with the nonvisual information contained in your head to create meaning. In thatway, what's in your head is just as important as what's on the page in the process of creating meaning (reading). Regrettably, the students' reading comprehension is still far from being satisfactory.

It can be seen from the result of National Examination in which the test is mainly in the forms of reading texts. However, many students fail to achieve the minimum score of English subject expected. The fact also shows that the students' problem in comprehending texts is their limited number of vocabulary. If students encounter some new words, they will ask the meaning to other students around them straightforwardly or they will look up their dictionary to get the meaning immediately. These conditions occur because the method utilized by the teacher stresses more on product than process. 
Teachers usually do not pay attention the learning process but the result of the learning. Teachers are more concerned with the score students obtain rather than the process of making students understand. Besides, teachers usually utilize conventional method, like Grammar Translation Method, to teach reading. Sometimes, students read silently or loudly a reading text, and after that the teacher translates the text for students. In other times, the teacher reads the text, and afterwards, one or two students read the text again prior to answering the questions provided.

To enrich their classroom procedures, teachers have to read a lot of related theories to be employed in their classroom. However, in teaching learning process, it is often found that teachers encounter gaps between theory and practice. Therefore, teachers are encouraged to develop their own personal theories of education from their own class practice. Reading is also something crucial and indispensable for the students, because the success of their study depends on the greater part of their ability to read. If their reading skill is poor they are very likely to fail in their study or at least they will have difficulty in making progress.

On the other hand, if they study good ability in reading, they will have a better chance to succeed in their study. In reading, you improve your skill of reading first before you develop skill for answering questions. Do not be put off by the fact that we are not starting with normal comprehension questions. Do not neglect the skill of reading for meaning. After all, if you comprehended everything perfectly (as these skills help you to do), you stand a chance of scoring full marks later.

In contrast, no matter how exam-smart you become at answering question, you will never get full marks if you do not understand what you are reading. Reading comprehension is a cognitive or behavioral action that is enacted under particular contextual conditions, with the goal of improving some aspect of comprehension. Reading comprehension refers to the ability to go beyond the words, to understand the ideas and the relationships between ideas conveyed in a text. The focus of this book is on the cognitive processes involved in comprehension, and moreover, on techniques that help readers improve their abilityto comprehend text. To know what you are reading about, we need a certain method.

You are tackling comprehension exercise; you do not have many of the guides that a newspaper or magazine provides - photographs, captions titles or even sub-headings. It becomes even more important; therefore, have to a method for finding meaning. The first step in this method is skimming. Skimming means that you glance through the text quickly to discover what the text is about in a text length of an ' $\mathrm{O}$ ' level comprehension passage, the reader should be able to achieve this within two minute. A simple way of doing this, the one recommended in this series, is to read the first sentences or first lines of all paragraphs to find the meaning.

Linguists: Journal of Linguistics and Language Teaching

Vol. 6, No. 1, July 2020 
Narrative is description of events especially in a novel, fables or legend, etc, or a process of skill of feeling a story. Thus narrative tells about the event which happened in the past time. In generally the tense that is often used in narrative is past tense form. We can see it from the definition about past tense is a tense used to describe actions or events which took place in the past. Based on the explanation above, the researchers are interested to conduct a research entitled The effect of skimming method to improve students' ability in reading comprehension on narrative text.

\section{METHOD}

\section{Research Design}

The design for this research is the quasi-experimental design. Quasi experimental design uses experimental and control groups, but no random assignment of subjects. This research method is used to describe variables, to examine relationships among variables and to determine cause-and-effect interactions between variables (Burns \& Grove, 2005:23). This study intended to find out the effect of skimming teaching technique to the reading comprehension of grade XI of SMK Negeri 2 Pematangsiantar. The researchers used quantitative research. Quantitative research deals with research methodology which focuses on the result. In conducting the experimental research, the sample was divided two groups, namely the experimental group (using skimming teaching technique to the reading comprehension in a narrative text ) and control group (without using skimming teaching technique in a narrative text).

Since there are several categories in quasi-experimental design, pre-test and post-test group design is used in this research. The pre-test and post-test are administered to both groups with the following formula :

Table 1. Quasi Experimental Study

\begin{tabular}{lccc}
\hline Sample & Pre-test & Treatment & Post-test \\
\hline Experimental group & $X I T K B B^{1}$ & $\mathrm{~T}_{1}, \mathrm{~T}_{2}, \mathrm{~T}_{3}, \mathrm{~T}_{4}$ & $X I T K B B^{1}$ \\
\hline Control group & $X I T P^{2}$ & $\mathrm{~T}_{1}, \mathrm{~T}_{2}, \mathrm{~T}_{3}, \mathrm{~T}_{4}$ & $X I T P^{2}$ \\
\hline
\end{tabular}

Where:

$\begin{array}{ll}X I T K B B^{1} & : \text { Students' reading skill of experimental group in pre-test } \\ X I T K P^{2} & \text { : Students' reading skill of control group in pre-test } \\ X I T K B B^{1} & : \text { Students' reading skill of experimental group in post-test } \\ X I T P^{2} & : \text { Students' reading skill of control group in post-test } \\ \mathrm{T} & : \text { Treatment using Skimming teaching technique }\end{array}$




\section{The Population and Sample}

\section{Population}

According to Arikunto (2013:173), population is defined as all members of any welldefined class of people, events, or objects. Population is also the group of the people that you want to find out about by doing your research.

In this research, the researchers will take grade XI students of SMKN 2 P.Siantar. There are three classes of Grade XI with the total number of 100 students. The table as follows:

\begin{tabular}{cc}
\hline GRADE & TOTAL \\
\hline XI TKBB 1 & 20 \\
\hline XI TP 2 & 20
\end{tabular}

\section{Sample}

Arikunto (2013:174) stated that the sample is any number of things, people, or events which are less than the total of population. Sample is a part of population that will be investigated. The researchers take the sample freely, also based on the students' number in a class.

Sample is represent of population which is researched, Arikunto (2013:148). The researchers take a sample based on the number of students at grade XI. The three classes with 100 students are selected randomly. The researchers use the random sampling with the traditional technique in choosing the sample. One class is grade XI TKBB 1 with 20 students is chosen to be the experimental group and the other one class is grade XI TP 2 as the control group.

\section{The Instrument of the Research}

Arikunto (2013:192) states that instrument is a tool when the researcher using a method. There are several kinds of instruments. By considering and situation, the researchers use the enclosed questionnaire of multiple choice questionnaires because it can be shared simultaneously and can be answered by the respondents according to their speed. In applying the skimming method, the researchers sequence the class activity based on the procedures are as follows :

1. The researchers make sure whether the students have really understood the procedure or not.

2. The students prepare themselves to begin their test.

3. The researchers give the instruction once and explains how to do the tests. 


\section{The Technique of Data Collection}

\section{A. Pre Test}

Before the treatment (teaching presentation), pretest is given to both experimental and control group. Arikunto (2013:293) states “"Using pretest may increase or decrease the experimental subjects' sensitivity or responsiveness to the experimental variable and thus make the results obtained for this pretested population unrepresentative of effects of the experimental variable on the un-pretested population from which the experimental subjects are selected". It aimed to find out the homogeneity of the sample about descriptive writing which will be showed by the calculation of the mean score both of group.

\section{B. Treatment}

The experimental group and control group were taught by using the same materials but in different instruments. The experimental group is taught with using skimming technique. Meanwhile, the control group is taught without using skimming technique. This is applied in the treatment only because it was be expected to procedure different of the test at post test, to find out the effect skimming technique to the reading comprehension in a narrative text.

\section{a. Treatments in Experimental Group}

\begin{tabular}{ll}
\hline \multicolumn{1}{c}{ Teacher } & \multicolumn{1}{c}{ Students } \\
\hline The teacher will give greeting & Answer the teacher \\
\hline The teacher will give brainstorming to the students & Response the teacher \\
\hline The teacher will give commands to the students & The students response the commands physically \\
\hline $\begin{array}{l}\text { The teacher ask the students to read the narrative } \\
\text { text }\end{array}$ & The students read the narrative text \\
\hline The teacher explain about skimming & The students will give attention to the teacher \\
\hline The teacher will give the example of narrative text & The students give the attention to the teacher \\
\hline The teacher read the narrative text & Look at the teacher \\
\hline $\begin{array}{l}\text { Ask the students to read the narrative text using } \\
\text { skimming method }\end{array}$ & Practice it \\
\hline $\begin{array}{l}\text { The teacher ask the students to find out the main } \\
\text { idea after reading the narrative text }\end{array}$ & Students do the command \\
\hline $\begin{array}{l}\text { As the evaluation teacher will ask them to answer } \\
\text { the multiple choice after reading the narrative text } \\
\text { one time }\end{array}$ & Students answer the questions \\
\hline The teacher will evaluate the students' work & \\
\hline
\end{tabular}

\section{b. Treatments in Control Group}

\begin{tabular}{ll}
\hline \multicolumn{1}{c}{ Teacher } & \multicolumn{1}{c}{ Students } \\
\hline $\begin{array}{l}\text { The teacher will give brainstorming about the topic } \\
\text { that will be learnt, it narrative text }\end{array}$ & Students answer the question \\
\hline The teacher will explain about skimming & Students listen to the teacher explanation \\
\hline $\begin{array}{l}\text { The teacher will ask the students to read the text } \\
\text { using skimming method that are related to the }\end{array}$ & \\
narrative text & \\
\hline The teacher will evaluate the students' work & \\
\hline
\end{tabular}


The test is taken from the text given by the researcher. It is multiple choices that consist of 20 items and each item consists of four options. This test is prepared in order to know the effect of using skimming teaching technique to the reading comprehension in a narrative text.

\section{Post Test}

The post-test is given after the treatment has been completed. Having treatment, the entire subject is given a post test as the pre test before. The post test is used to know the effect of skimming teaching technique in experimental group.

\section{The technique of Data Analysis}

Data analysis is the last step in the procedure of research. In analyzing the data from the pre-test and post test, the researcher used the statistical calculation of T-test (Paired sample) in order to calculate the pre and post test results. The steps for data analysis technique:

1. After the researchers get all the students' score from the pre test and post test in experimental group and control, the researchers calculate the total score of pre test and post test from each group the researchers calculate means of pre test and post test from each group.

The formula (mean) : $\mathrm{X}=\frac{\sum x}{N}$

The researchers find the highest and lowest score from each group. And the researchers makes the conclusion.

2. The researchers analyze the level of ability of the students in experimental group and control group by calculating the raw score of students in experimental group and control group.

Analyzing the result by using statistic calculation of t-test :

$$
t=\frac{M x-M y}{\sqrt{\left(\frac{\sum x^{2}+\sum y^{2}}{N_{x}+N_{y}-2}\right)\left(\frac{1}{N_{x}}+\frac{1}{N_{y}}\right)}} \text { Arikunto 2013:354) }
$$

Where:

Mx: Mean of experimental group

My : Mean of control group

$\sum x^{2} \quad$ : Sum of square deviation of experiment class

$\sum y^{2}$ : Sum of square deviation of control class

$\mathrm{Nx} \quad$ : Number of students in experimental group

$\mathrm{Ny} \quad$ : Number of students in control group 
3. The researchers calculate the means of experimental group (Mx) and control group (My). The researchers also calculate the standard deviation of experimental group ( $\mathrm{dx}$ ) and the standard deviation of control group (dy).

4. Testing the T-test formula. The T-test formula is used to find out T-count.

The form :

$$
\mathrm{t}=\frac{M x-M y}{\sqrt{\left[\left[\frac{d x^{2}+d y^{2}}{|N x+N y|-2}\right]\right]\left[\frac{1}{N_{x}}+\frac{1}{N_{y}}\right]}}
$$

Where :

$$
\begin{array}{ll}
\text { Mx } & \text { : Mean of experimental group } \\
\text { My } & \text { : Mean of control group } \\
\mathrm{dx} & \text { : The standard deviation of experimental group } \\
\mathrm{dy} & \text { : The standard deviation of control group } \\
\mathrm{Nx} & \text { : Total sample of experimental group } \\
\mathrm{Ny} & \text { : Total sample of control group }
\end{array}
$$

5. The last is testing hypothesis. To test the hypothesis, the data are adapted to the T-test formula chosen. It is done to know whether the hypothesis is accepted or rejected. If the t-count is found to be smaller than the table, it means that the null hypothesis is accepted and the alternative one is rejected. Vice versa, if the t-count is found to be higher than the t-table, it means that the null hypothesis was rejected and the alternative one is accepted. It can be said that $H_{o}$ has been rejected than $H_{a}$ has been successfully accepted.

So, the effect of skimming teaching technique to the reading comprehension in a narrative text is really accepted in this research.

\section{FINDINGS AND DISCUSSION}

After the researchers have done a research and has collected the data and then the researcher calculated the data, the researcher got some findings from the result of data calculation. Some findings can formulate as follow:

1. The effect of skimming method can increase the students' ability in reading narrative text to the ability of grade XI students of SMK N 2 Pematangsiantar. It can be looked from the grouping of students' scores in post test of experimental class which the treatment the researchers did the treatment by using skimming method because it makes the students able to answer the multiple choice from the example of a narrative text. By using skimming method, the students can increase their ability in analyzing a story or legend. 
2. The effect of without skimming method is not interesting, and can not increase the students' ability in reading narrative text to the ability of grade XI students of SMK N 2 Pematangsiantar. In can be looked from the students' scores in post test of control class. The students got the low scores because they can't answer the multiple choice .

3. The effect of skimming method to the reading comprehension is more significant than the effect of without skiming method to the ability of grade XI students of SMK N 2 Pematangsiantar. It can be proved from the t observed value was 0,25 and the value of t table was 2.00 at alpha 0.05 and df $38(n+n-2=20+20-2)$. "The value of t-test was higher than the value of t-table (t-test> t-table". Therefore, the Alternate Hypothesis (Ha) was accepted and the Null Hypothesis (Ho) was rejected.

\section{DISCUSSIONS}

Based on the results calculation of the findings above, the result of t-test was 3,8, and was higher than t-table (2.00). In the hypothesis testing, it was shown that the Alternate Hypothesis was accepted ( $>2.00$ ). It means that there is a significant effect of using skimming method in reading narrative text to the students. It was proved from the data showing that the score of experimental class (using skimming method) was higher than the score of control class (without using skimming method).

Based on the explanation above, the researchers found that using skimming method is interesting technique to be applied in classroom by the teachers and the students than without skimming method because :

1. Teacher is not the sole provider of knowledge. Skimming every student is an expert and every student can be a teacher for teaching each other according to what they have learned. It means that teacher role is as counselor. Not only one provider but the teacher is helped by the expert.

2. Efficient ways to learn, skimming is one of effective teaching method in teaching reading. Here the students do not need read a long text, even the story is composed by long text because in skimming every student has own piece text, so it will make the student faster in reading.

3. Students take ownership in the work and achievement it means the students are claimed to be responsible of their own task and they should be able to be responsible to what they have read to the other to organize be complete task.

4. Learning revolves around interaction with peers, it means every student will be done exchange knowledge each other. So in the end of the learning process the student will get the complete information even they only read their own part should be responsible to do their task.

Linguists: Journal of Linguistics and Language Teaching

Vol. 6, No. 1, July 2020 
5. Built interpersonal and active skills, skimming is a cooperating teaching method where the students work in a group, so it will bring the student to make a relation, cooperate, and share each other for finishing their task.

6. Without skimming method, student faced the difficulties to find the main idea from the narrative text, and they can't to answer the multiple choice correctly because they must reading the narrative text again to find the right answer.

7. The students' score of reading taught by using skimming method is better. It means that the use of skimming method in teaching reading is quite effective. Another reason based on the students response is because most students find that skimming method is enjoyable.

8. The problem that they faced mostly is lack of confidence and lack of vocabulary. In the early stages of skimming method the students were uncomfortable and certain. This led to initial lapses of silence. But soon they began helping one another to decide what to do. Towards the end, their shyness left them and they began prompting each with ideas.

\section{CONCLUSION}

After collecting and analyzing the data presented in the previous chapter, that conclusion earn in taking at the time of student read with the correctness and ability, because the ideas and concepts of the reading models as to be applied. It was gaining the theory of the reading models as the basis to design the skimming method, so the researchers got some conclusions as follow:

1. The effect of using skimming method can increase the students' ability in reading narrative text to the ability of grade XI students of SMK N 2 Pematangsiantar. It can be looked from the students' scores in post-test of experimental class which the treatment the researchers did the treatment by using skimming method because it makes the students able to read text from the example of a narrative text even it is the main idea. By using skimming method, the students can increase their ability in analyzing a narrative text focused on lexico grammatical features, material processes, temporal conjunctions, and tenses.

2. The effect of without using skimming method is not interesting, and can not increase the students' ability in reading narrative text. In can be looked from the students' scores in post test of control class. The students got the low scores because they can't to find the main idea from the narrative text.

3. The effect of using skimming method is more significant than the effect of without using skimming method in teaching reading comprehension of grade XI students of SMK N 2 Pematangsiantar on narrative text. It can be proved from the t observed value 
was 3,8 and the value of $t$ table was 2.00 at alpha 0.05 and df $38(n+n-2=20+20-2)$. "The value of t-test was higher than the value of t-table (t-test> t-table". Therefore, the Alternate Hypothesis (Ha) was accepted and the Null Hypothesis (Ho) was rejected.

4. The development of the student reading comprehension individually is also significant improve so skimming method is very suitable to increase and punctuality students in reading ability.

5. The mean of experimental class is 57,75 and the mean of control class is 53 . The validity of experimental class is 1,72 and the validity of control class is 0,79 , and the reliability of experiment class is 0,80 and reliability of control class is 0,88 .

\section{REFERENCES}

Arikunto, S. (2013). Prosedur Penelitian, Suatu Pendekatan Praktek, Jakarta: Bumi Aksara

Brown, D. (2003). Language Assessment Principle and Classroom Practice, San Fransisco, Callifornia: Longman

Burns, N. \& Grove, S. K. (2005). The practice of nursing research: Conduct, critique, and utilization (5th ed.). St. Louis: Elsevier Saunders

Grabe, S. (2011). Teaching and Researching Reading, New York and London: Routledge

Hedgcock, J. and Ferris, D. (2009). Teaching Readers of English, New York and London: Routledge

Herman. (2014). An Experiential Function on Students' Genre of Writing. Jakarta: Halaman Moeka Publishing

Herman, Sibarani, J. K., and Pardede, H. (2020). The Effect of Jigsaw Technique in Reading Comprehension on Recount Text. Cetta: Jurnal Ilmu Pendidikan. Jayapangus Press, ISSN 2615-0891 (E). Vol. 3 No. 1 (2020). PP. 84-102

Hutajulu, F. S. L and Herman (2019). Analysis of Illocutionary Act in the Movie "You Are My Home” English Subtitle. Journal of English Educational Study. Volume 2 Issues 1 May 2019 Page 29-36. E-ISSN: 2655-0776

Larsen, D. (1990). Language Teaching Method, Washington DC: Usia Worldnet

Meng, J. (2010). Jigsaw cooperative learning in english reading. Journal of Language Teaching and Research, Vol. 1, No. 4, pp. 501-504. Finland

Micklukey, J. (2007). More Reading Power, United State of America: World Language Division

Nunan, D. (1991). Language Testing Methodology, Sydney: Prentice Hall

Pasaribu, B., Herman and Hutahean, D. T. (2020). Students' difficulties in translating narrative text from English into Indonesia at grade VIII of SMP Negeri 9 Pematangsiantar. Acitya: Journal of Teaching \& Education Vol. 2 No. 1 2020, PP. 12-18

Linguists: Journal of Linguistics and Language Teaching

Vol. 6, No. 1, July 2020 
Bobby Pramjit Singh Dhillon, Herman, \& Syafryadin

Thornburry, S. (2002). How to Teach Vocabulary, England: Pearson Longman

Willis, J. (2008). Teaching the Brain to Read Strategy for Improving Fluency, Vocabulary and Comprehension, Alexandria, Virginia USA: ASCD (Association for Supervision and Curriculum Development)

http://www.studygs.net/. The SQ3R Reading Method-Study Guides and Strategies. Html (online) accessed 